\title{
ПОВСЕДНЕВНОСТЬ И ДУХОВНОСТЬ - «ГОРИЗОНТАЛЬ» И «ВЕРТИКАЛЬ» БЫТИЯ
}

\section{И.А. Филина}

Среди всех параметров, призванных отразить качественные характеристики общества или выразить меру его прогресса, особое место принадлежит духовности. Этот мощный, но невидимый феномен притягивает философские умы неслучайно, так как именно духовность является, пожалуй, главным измерением гуманности общества, его моральной культуры, а также уровня образованности и мировоззренческих позиций отдельных его граждан. Наибольшее число духовных проблем обусловлено преимущественно аспектами повседневности, поэтому исследование взаимосвязи двух смысловых координат бытия по-прежнему остается весьма актуальным.

\section{1 Повседневность}

Мир повседневности, окружающий нас и не отпускающий своей неизбежностью, вроде бы и не требует особых доказательств и характеристик. Это есть тот мир, от которого нельзя уйти, как от самого себя. Абсолютное большинство людей, погруженных в повседневность, воспринимают ее как то, что всегда есть и никуда не денется. Причем смысл существования в мире повседневности как бы подразумевается сам собой и специально не ищется.

Обыденный мир воспринимается как единственно-реальный и непосредственно-переживаемый. Это мир забот и впечатлений, конкретных практических действий и тревог, страстей и иллюзий, мнений и слухов, социальных норм и домыслов. Все пространственно-временные характеристики обыденного мира имеют единое начало - самого человека, который, к тому же, и не сомневается в том, что именно он-центр мира.

Актуальні проблеми духовності

(Відп. ред.: Я.В. Шрамко)

Кривий Ріг (2005), 3-21 
Повседневность, действительно, очеловечена и опредмечена: дома, поля, машины, приборы, вещи сделаны людьми и для людей. В этом мире не суть важно то, что было когда-то во тьме веков, или то, что в космосе есть другие планеты и звезды. Обыденное сознание людей ориентировано на текущий момент и ближайшее будущее, оно ценит только то, что «Здесь и сейчас», и еще то, что будет непосредственно «завтра и со мной».

Все попытки выйти за обыденные пределы чувственно-переживаемого мира, все шаги в непонятное и зыбкое (будь то прошлое или далекое будущее, абстрактно-научное или ирреально-фантастическое) оцениваются не иначе как «философствование», порой как чье-то преднамеренное желание спутать привычное и понятное с какой-то темной, пугающей целью. . .

Тем не менее, ежедневное существование, как и существование вообще, нуждается все же в элементарном осмыслении, анализе, прогнозировании. Однако ракурс видения повседневного мира, выделяемые ценности как смысловые комплексы, определяющие поведение людей, уровень языковой культуры, с помощью которой выстраивается модель чувственно-переживаемого мира - все это еще не отличается достаточной глубиной, логичностью, объективностью, научной аргументацией. Как правило, понимание обыденного мира проявляется не иначе как простое мироощущение и чувственное мировосприятие, реализующиеся в формах общественной психологии и эмпирической практики. Рациональное обустройство существования, прагматизм, самоутверждение, богатство, сила, власть - вот основные критерии обыденного мышления, исходящего от потока повседневного бытия.

Одним словом, обыденный мир образует своего рода «горизонталь» бытия, где можно двигаться в основном «вширь». Как любая другая горизонталь, она служит основой, опорой для более совершенных «вертикальных» конструкций, самой «несущей» из которьг является «вертикаль» духовности. С точки зрения механики, чем шире основание, тем прочнее вертикаль. Вертикаль обрушивается, когда основание узкое или рыхлое. В философии, культурологии, социологии все выглядит значительно сложнее, хотя, пожалуй, основные «механические» закономерности сохраняются.

Философской категорией, отражающей «горизонталь» повседневности, служит «обыденная картина мира», которая формируется на базе чувственно-практической эмпирии. Равно как и другие «картины мира» (религиозная, научная, эзотерическая), обыденная картина мира имеет свой смысловой центр и свой комплекс ценностей, удерживающий мировоззренческие суждения людей на этом уровне в качестве единого целого. Другими словами, «горизонталь» бытия имеет некое цементирующее начало, предшествующее возведению «вертикали» духовности. Таким началом служит здравый смысл. Люди тысячелетиями возделывали землю, 
строили жилища, любили, воевали, страдали. Здравый смысл как опыт многих поколений, как мудрость жизни способен придавать некую фундаментальную целостность обыденному бытию. Здравый смысл закрепляется и передается через приметы, предания, верования, наставления, традиции. В переломные эпохи здравый смысл может даже противостоять воинствующей бездуховности. Пропитанная здравым смыслом повседневность приобретает как бы особую устойчивость и надежность. От здравого смысла, как от «подножия», через посредство магии, мифологии и религии начинается возведение духовной «вертикали».

\section{2 Духовность}

Потребность в невещественных и невидимых духовных высотах человечество почти подсознательно испытывало всегда. Мечта и фантазия первыми помогают воспарить над привычным до скуки эмпирическим миром. Религия и искусство становятся первыми «иными мирами», рожденными сплавом мистики, мифологии и народной поэзии. Эстетическая идеализация была наиболее простой и доступной формой преображения действительности, несущей временное забвение от грубой и суровой жизни, придающей возвышенное очарование миру повседневности. Позже подключаются философия и наука, претендующие не столько на отвлечение от обыденности, сколько на «истинное» объяснение мира в целом. Они уже опираются не так на эмпирический опыт, как на теоретические основания, отдавая приоритет не чувственности, а рациональности. (Возведенные «иные миры» не отрываются от обыденности, они всегда сохраняют укорененность в практическую и осязаемую почву повседневности. Так, от соблюдения ритуалов и молитвы люди ждут зримых плодов божественной помощи: успехов, здоровья, исполнения заветных желаний. От философии ждут готовых рецептов смысла жизни, бессмертия, счастья. От науки - новых изобретений и открытий, повышающих производительность и комфортность труда. В мире обыденности высокотеоретические идеи часто могут выступать лишь в качестве служебных, чисто функциональных - неважно знать физические или математические принципы устройства компьютера, главное - знать, какую кнопку нажимать.)

Сама потребность в умозрительных мирах реализуется в разные исторические эпохи по-разному. Прежде всего это зависит от общего уровня культуры, как общественной, так и личностной. Простое наличие или простая сумма «иных миров» (сколько бы их ни было в ту или иную эпоху) еще не позволяет объяснить сам феномен духовности. Духовность представляет собой некую систематизацию умозрительных миров человека, порождающую своеобразную «вертикаль» ценностей. Духовность прояв- 
ляется в итоге как некий идеал, к которому стремится (или должен стремиться) человек и человечество. Полнее всего духовность воплощается в религии, философии, искусстве, языке. Смысловые контуры духовности выступают как потребность и как способность ориентации человека на высшие ценности, прежде всего Добра, Истины и Красоты.

Система высших универсальных ценностей охватывает жизнь во всей ее полноте и насыщенности. Разум, как ни стремился охватить мир универсальной «сеткой» понятий и логических форм, смог все же отразить лишь сущность мира, а не его существование. «Суха теория, мой друг, а древо жизни пышно зеленеет» - заметил Гёте. Пышно зеленеющее «древо жизни», пожалуй, - самый удачный образ человеческого бытия. Есть «корни», «ствол», «ветви», «листья», образующие одновременно и смысловую «вертикаль» ценностей, и устойчивую плоскость, «горизонталь» обыденного существования, где все наглядно, привычно и ясно. «Ствол» как бы соединяет и одновременно упорядочивает все разнообразие существования, все его уровни. Более того, от высоты «вертикали» духовности зависят и способы организации «горизонтали» повседневности. Для одного «горизонталь» - это библиотеки, театры, университеты, вернисажи и симпозиумы, а для другого - карты, телевизор, выпивка и сдача бутылок. Истинная духовность помогает выйти за утилитарно-очерченные границы повседневности, соотнести сиюминутное с вечным, свою жизнь - с историей всего человечества. Духовность никак не обходится без глубинного осознания человеком смысла собственного бытия. Именно она служит основополагающим принципом становления личностного начала в человеке, служит своеобразной опорой его внутреннего мира.

\section{3 Возведение «вертикали» ценностей}

Ценностями в самом широком смысле называют смысловые комплексы, определяющие поведение людей. Ценности обыденного мира порождены, несомненно, здравым смыслом. От них до Высших Ценностей человечество прошло длительный и трудный путь. Ценности как таковые составляют смысловой фундамент человеческой культуры вообще. Само понятие «ценность» впервые ввел в философию и социологию немецкий мыслитель Макс Вебер, понимавший под этим нечто более значимое, чем просто общее для всех явление или закономерность. Ценности для Вебера не что иное как осознанный интерес. Именно в сфере интересов можно оценить любой предмет или действие с точки зрения добра и зла, истины и лжи, красоты и уродства. В отличие от философа Генриха Риккерта, полагавшего, что ценности вечны и универсальны, Вебер рассматривал ценности как порождение конкретной эпохи, как явление 
историческое, определяемое тем или иным приоритетным интересом, тем или иным способом осознания общественных потребностей. Уже основные сферы существования первобытного человека охвачены насущными потребностями, которые не имели непосредственного биологического значения - ритуальные танцы, погребальные обряды, обучение, магические действия. Именно они закладывали основу первых ценностных комплексов.

Благодаря осознанным общественным потребностям и социальным интересам человек в своей жизни смог руководствоваться образом должного, а не реального, еще не существующего порядка вещей. В связи с этим должные ценности создавали особый мир духовного бытия, который и возвышал человека над повседневностью. Ценности, развиваясь и множась, помогали человеку выстраивать социально-привлекательные миры возможной действительности. Одним словом, вырастая из социальных потребностей, ценности все более приобретали идеализированные черты, давая возможность лицезреть две плоскости бытия - реальную и идеальную, отводя идеальному миру роль образца.

Социальная основа идеальных ценностей всегда дополнялась интеллектуальными усилиями в отношении их обоснования, сопровождалась теми или иными способами их рационального закрепления. В построение «храма» ценностей внесли свой вклад в первую очередь мифология, религия, философия. Так, мифология закрепила не только образное и эмоциональное восприятие мира через гилозоизм, анимизм, антропоморфизм, но и прочное отношение к природе как к неизмеримо превосходящей человека силе. Отношения между людьми и природными силами понимались как чуткие и подвижные: реки могли гневаться, горы содрогаться, моря бушевать в ответ на непочтительные действия человека. Отсюда в оценке окружающего мира возник идеал гармонии, изначального совершенства, образца организации. Этот идеал гармонии мира был уже чем-то большим, чем просто поэтическим образом или аллегорией, ибо от человека уже требуются определенные моральные усилия, гарантирующие ненарушение гармонии. Первые философские размышления о природе были предопределены именно такой позицией, которая, например, у греков вылилась в понятие «космос», охватывающим всю видимую и доступную разуму природу, а жизнь в согласии с природой считалась идеалом, достойным мудреца. Идеал гармонии, согласия, который относился к числу первых неутилитарных и высших ценностей, предполагал, соответственно, наполнение и повседневной жизни разумностью, справедливостью, рассудительностью, спокойствием.

Античная философия, кроме самого космологизма в осмыслении мира, дала еще и целую череду фундаментальных рационалистических понятий, которые впоследствии теоретически укрепили «вертикаль» духов- 
ной культуры: «логос» (Гераклит), «бытие» (Парменид), «благо» (Платон). Все они были рождены желанием описать и объяснить несомненно существующий порядок мира, о котором люди должны знать и помнить. Это был прежде всего тот должный порядок, тот идеал, к которому, высоко ценя его, следует стремиться всем и всегда. Так, у Гераклита понятием «логос» выражается внутренняя закономерность мирового процесса, всеобщая смысловая связь сущего. Гераклитов «логос»это принцип порядка и меры в Космосе, разумная необходимость сущего, слитая с самим понятием сущего (= огня). Огонь выражает качественную и изменчивую сторону существующего, логос-структурную и устойчивую. Поскольку «логос» означает и слово, и речь, и довод, и учение, то он означает нечто разумное, выражает сквозную смысловую упорядоченность и бытия, и мышления. Логос-«разумное слово» природы, говорящей с человеком, хотя и не всякому доступное. Будучи огненной, человеческая душа, по Гераклиту, владеет самовозрастающим логосом таков объективный закон Космоса. «Желающим говорить разумно следует укрепить себя этим логосом, подобно тому как город (укрепляется) законом, и намного крепче. Ибо все человеческие законы питаются одним божественным, который простирает свою власть насколько пожелает, всему довлеет и над всем одерживает верх» ${ }^{1}$. Гераклит осознал и отчетливо выделил два плана сущего: непосредственное, наличное существование вещей и его внутреннюю природу. Их соотношение выражается у него через понятие все той же гармонии, даже двух гармоний: «скрытой» и «явной». Скрытая, внутренняя гармония сильнее явной, считает Гераклит. Внутренняя гармония обусловливается напряжением противоположно направленньг сил, действующих всегда одновременно. В подтверждение этой глубокой мысли Гераклит приводит такой пример: оба дугоподобных конца лука стремятся разогнуться, но тетива сдерживает их, и их взаимное действие создает высшее единство. Но несмотря на то, что логос господствует над всем и все упорядочивает, люди часто утрачивают связь с логосом. Это происходит тогда, когда они ограничивают себя поверхностными обыденными знаниями и становятся склонными к чувственно-телесным наслаждениям (то есть погрязают в повседневности).

Гераклит резко осуждал неспособность понять внутреннюю суть мира и погоню за наслаждениями, что было, на его взгляд, почти одним и тем же. Но каждый человек, считал он, всегда имеет возможность возобновлять и усиливать непосредственную связь с логосом через философские размышления. «Мышление - это великая ценность, и мудрость состоит в том, чтобы говорить истинное, и чтобы, прислушиваясь к природе, дей-

\footnotetext{
${ }^{1}$ Цит. по: Богомолов А.С. Античная философия.-М.: Изд-во Моск. ун-та, 1985.C. 55 .
} 
ствовать согласно с ней» ${ }^{2},-$ советовал Гераклит. Познание скрытой гармонии, которая лучше явной,- верный способ избежания высокомерия. Такое познание позволяет преодолеть пестроту взглядов и сосредоточиться на достижении единой истины, обеспечивающей взаимопонимание и объединение людей. Как видим, гераклитов «логос» не просто космообъясняющий термин, но и своего рода моральный стержень, удерживающий социальный мир. В основу возводимой «вертикали» духовности закладываются такие ценности, как единая истина, философствование, внутренняя гармония - все то, что упорядочивает мир природы и мир людей.

Свой вклад в возведение духовно-рациональной «вертикали» внесли также элеаты и Платон. В V-IV веках до н.э. античный мир переживал своего рода мировоззренческий кризис, отразивший разрушение мифологических основ и духовных норм того мира, главными опорами которого были олимпийские боги и народные традиции. Тогда, во времена Парменида, вера в богов Олимпа сильно пошатнулась, а мифология стала считаться выдумкой. Вместе с этим возникло ощущение утраты какой-то важной жизненной основы, мир уже не казался прочным и надежным. Философия Парменида в какой-то мере отразила сложившуюся ситуацию. Более того, она принесла некоторое успокоение, поставив на место власти и силы богов силу разума. И это была не обычная мысль о вещах и процессах мира или о потребностях повседневного существования - это была абсолютная мысль. Парменид провозгласил об открытии абсолютной мысли как абсолютной силы, которая удерживает мир от опрокидывания в хаос и обеспечивает миру стабильность и надежность. Воплощением силы абсолютной мысли стало понятие «бытия» как нечто неизменное, вечное, тождественное себе и доступное только мышлению. Главным для Парменида является именно мыслимость, а не телесность сущего. Мышление - это прежде всего способность постигать единство, в то время как чувственному восприятию открывается множественность и многообразие в вещах и явлениях. Бытие означало сущее, которое не имеет частей, поэтому вполне закономерным был выход и на понятие «единого». У Зенона, Платона и неоплатоников оно окажется в центре внимания и в дальнейшем получит все возрастающую перспективу востребованности.

Обращаясь к понятию «единое» как к гаранту существования и порядка, Платон толкует его иначе, чем Парменид и все элеаты. «Единое» само не есть бытие, оно выше бытия, говорится в платоновском диалоге «Парменид», и составляет условие возможности бытия, то есть идей. Согласно

${ }^{2} Ц$ ит. по: Філософія. Підручник / За заг. ред. Горлача М.І., Кременя В.Г., Рибалка В.К. - Харків: Консум, 2000.- С. 81 . 
Платону, единое выше всякого существования и всякой множественности, но без его объединяющей силы невозможны ни сами идеи, ни их множественность. Такое «единое» Платон отождествляет с высшим «благом», к которому все стремится и через это получает собственное бытие. Само же высшее благо - по ту сторону всякого бытия и, следовательно, недоступно разуму. Впоследствии платоновское «благо» трансформируется в трансцендентального Бога, но это произойдет уже в христианстве. Христианский Бог (равно как и боги других монотеистических религий) окончательно венчает столь долго возводимую «вертикаль» духовности и упорядочивает ее через установление несомненных связей между Богом и сотворенным им миром, а главное - через упрочение морального долга человека.

Доверие к разуму, столь хорошо обоснованное элеатами, также будет впоследствии возрастать, поскольку сам разум не раз продемонстрирует свою силу и гибкость. Христианство, по мере своего распространения и возрастающего влияния, само сильно ощутит потребность в рациональном обосновании догматов веры. Вначале использовался рациональный потенциал античных философов, но постепенно вырастает плеяда новых авторитетных мыслителей, поднимающих проблемы сущности и существования, соотношения веры и разума, духовного и телесного, высшего божественного разума и разума человеческого. Теоретические «леса», подпирающие «вертикаль» духовности были укреплены такими авторитетами как Альберт Великий, Фома Аквинский, Августин, Ориген.

Фома Аквинский, например, выстраивает иерархическую картину мира согласно идее о степенях совершенства, опираясь как на христианскую теологию, так и на учение Аристотеля о материи и форме, придающей определенность вещам. Под высшим началом он понимает само бытие, а бытие есть не что иное как христианский Бог, сотворивший мир. Начиная с Бога, который есть чистый акт бытия, по мере движения вниз, а именно по мере убывания актуальности бытия существ, можно дойти до самых малейших и ничтожных творений.

Ориген был одним из первых философов, пытавшихся систематизировать христианские догматы и создать на их основе учение о человеке, который, на его взгляд, состоит из духа, души и тела. Именно эти «степени совершенства» - дух, душа и тело - образуют внутреннюю «вертикаль» личности, обусловливая либо ее праведность, либо греховность. Разумеется, самого термина «вертикаль» у Оригена нет, но суть изложена довольно четко. Дух - дар Божий, который всегда устремлен к Добру и Истине. Душа - подчиненное духу начало, это собственное «Я» человека, обладающее свободой воли и возможностью выбора между добром и злом. Низшая часть «вертикали»- тело должно подчиняться душе. И греховность человека вовсе не в том, что он имеет тело, смущающее своими 
страстями душу. Тело, как и вся телесность, вещественность мира - тоже творение Бога, а все, что Он творит, - хорошо и совершенно. Грех состоит в переворачивании данного Богом порядка вещей, то есть в переворачивании «вертикали». Истоки греха - в злоупотреблении человеком свободой выбора, и грех всегда там, где низшее правит высшим, где тело диктует душе, а связь с Богом через дух обрывается вовсе. Всякий раз, когда примитивное подчиняет себе более совершенное, в мир приходит зло. Надо сказать, что учение Оригена, пожалуй, наилучшим образом передает саму суть духовности, указывая на то, что «вертикаль» как гарант порядка заложена в самом человеке. Христианство, собственно, и открывает «внутреннего человека», который целиком обращен к Богу как к создателю и идеалу, без участия которого невозможно очищение и спасение человека от греховных помыслов и деяний. Чтобы заручиться божьей благодатью, необходимы определенные усилия души: с одной стороны-вера, непосредственное обращение к Богу через молитву с просьбами о помощи, с другой - правдивая исповедь, покаяние, которое по сути является критическим самоанализом личности, соотнесением себя и своей жизни с высшими ценностями, с должным.

Христианские размышления о духовном и телесном никогда не утрачивали своей моральной поучительности. Самое главное, что стоит помнить: душа наделена правом выбора между высшим и низшим, между духом и телом. Если душа слаба, она соскальзывает вниз, погрязает в грехе, если сильна, становится еще более несгибаемой, крепче (духом). Люди, крепкие духом, выживают при любых испытаниях: на каторге, в забвении, при инквизициях, идейном терроризме. Право выбора сочетается со свободой выбора, о которой также рассуждали немало. В чем, например, заключается свобода выбора, если путь каждого предопределен высшей волей, или где границы свободы, если вседозволенность уже пик греховности? Свобода - это умение самому себе запрещать греховное, как нечто низшее, отличая сиюминутное и кажущееся добро от добра истинного, высокого, которое отливается порой в невидимых и неосязаемых наощупь нормах и ценностях. Преодоление греховного всегда связано с определенными усилиями, напряжением, порой мучениями. И давно известно, что без страданий, без испытаний не могут окрепнуть и возвыситься человеческие души.

Возвышение - путь совершенствования души - исключает гнев, озлобление и месть. Возвышение означает преисполнение любовью, добром, участием, сопереживанием. Не возвысив душу, не стоит касаться плотского, телесного. В чем заключается первородный грех? Ведь он не в самой плоти, ибо и плоть - творение Бога, а все, что Он творит - хорошо. Адам и Ева, живя в блаженстве и благополучии, вообще не имели возможности страдать, они не прошли пути испытания и восхождения душ, они 
не познали трепета высоких чувств, а сразу ринулись в омут плотских наслаждений. Господь создал их с заведомой обреченностью на грех, который должен был послужить назиданием всему человеческому роду: не возвысив душу, не предавайтесь телесному, примитивному. Иначе теряется смысл божественного предназначения человека - быть господином природы, возвышаясь над ней (в том числе и над своей телесностью) силой Духа. Именно духа, а не разума, ведь бездуховное познание - путь в объятия греха. Змей-искуситель с древа познания есть символ бездуховного разума.

Тем не менее, авторитет рационального познания продолжал возрастать, несмотря на то, что сама религия всегда оставалась обращенной преимущественно к человеческим чувствам, тревогам и надеждам, а вовсе не к разуму. Однако, религия, утешая и давая моральные наставления, никак не могла обходиться без решения задач мироуяснения и аргументации своей картины мира. Как одна из исторических форм мировоззрения, религия просто не может не решать подобные проблемы, но в отличие от философии и науки, она никогда не выносит на первый план чисто интеллектуальные аспекты познания. Тем не менее, в эпоху позднего средневековья случилось так, что само богословие укрепило авторитет разума, провозгласив, что мир человеку дан не только во благо, но и в поучение. Пояснялось, что Бог явил свою мудрость как непосредственно, в виде Священного писания, так и в скрытой форме, сотворив природный мир. Призывы прочесть «книгу природы», истолковать заключенный в ней божественный план и тем самым восславить мудрость и всемогущество Творца не только способствовали развитию астрономии, физики, биологии, но и сыграли немалую роль в укреплении рационального компонента познания вообще.

Первые шаги естествознания, успехи ремесел, торговли и мануфактурного производства привели к существенной подвижке в возводимой веками церковью системе ценностей. Отдельный индивид и его труд приобретает куда большую значимость. Не только Бог, но и человек оценивается как творец: человек строит дома, мастерит орудия, пашет, шьет, рисует. Он-мастер, и многое может сам, без Бога. Вырастает новое самосознание человека: ощущение своей силы, таланта, достоинства. Именно этим объясняется культ художника-творца и апофеоз искусства (как искусности человека) в эпоху Возрождения, идеалом которого становится яркая, оригинальная и всесторонне образованная личность. Ослабевает характерное для средневековья убеждение в греховности и испорченности человеческой природы. И по мере того как человек осознает себя в качестве творца собственной жизни и судьбы, он оказывается неограниченным господином над природой. Человек начинает гордиться тем, что он - «венец творения» и потому - наивысшая ценность после Бога. 
Период становления промышленного капитализма открывает новые горизонты в познании природы и пределов ее полезности. Наступает эпоха научной революции, которая возносит на небывалую высоту экспериментальное естествознание, соединившее промышленное производство и науку. Знание, добываемое человеком, становится главной ценностью Нового времени. Известный афоризм Френсиса Бекона «Знание сила», отражающий дух этой эпохи, превращается в ее смысловой символ. Науке отводится миссия познания причинных связей природных явлений ради использования их на благо людей. Природа, которой (как низшей телесностью) в Средние века пренебрегают, и которой (как «божественным храмом») восхищаются в эпоху Возрождения, теперь понимается как объект интенсивной преобразовательной деятельности и как бездонная кладовая, из которой человек может черпать без меры и счета. («Природа - не храм, а мастерская, и человек в ней- работник», - говорил тургеневский Базаров.) Опытное естествознание выдвигает идею безжалостного «испытания» природы, у которой нужно вырвать все тайны, чтобы свести все ее качественное многообразие к небольшому числу строгих количественных законов. Практически ориентированное познание природы еще более возвеличило человеческий разум. Сложилось целое направление - рационализм, признающее разум основой познания и преобразования природного, а затем и социального, мира. Вертикаль духовных ценностей, хоть и сильно изменила основные приоритеты, тем не менее все еще крепка: Бог - создатель, природа - творение, человек творец. Счастье и благополучие обусловлены не столько божественной благодатью, сколько собственным усердием и трудом самого человека. Однако эту вертикаль фундаментальных ценностей все более пронизывает дух утилитаризма, где главной точкой отсчета становится чисто «земной» интерес, а критерием моральности - приносимая обществу польза. Значение повседневности начинает стремительно возрастать.

Одновременно продолжается восхождение разума. Новое время открывает разум в качестве главного инструмента (органона) познания, а эпоха Просвещения рассчитывает на широкое распространение научных знаний, полагая просвещение масс гарантом общественного прогресса. Ценность образованности, причем не богословской, а светской, приходит на смену ценностям веры и аскетических страданий. Авторитет разума и «разумного эгоизма» возвеличил одновременно и роль науки, и роль повседневного здравого смысла. Культ разума в философии породил ряд теоретических концепций, претендующих на всесторонний охват бытия системой понятий и категорий, дав яркие и совершенные образцы европейского рационализма. Однако при этом высшие идеалы духовности - Бог, Истина, Красота, Гармония - по-прежнему питали просвещенные умы и возвышенные души. Как же случилось так, что столь монументальная, 
столь долго и старательно возводимая «вертикаль» ценностей с идеалами Бога, гармонии и труда, среди которых Человек с его творческим разумом и достоинством занял едва ли не центральное место, все же начала разрушаться?

\section{4 Размывание «вертикали» ценностей}

Где и как возникает тот переломный момент в мировой культуре, когда повседневность начала теснить духовность? Пожалуй, отсчет стоит начать с эпохи «разумного эгоизма», то есть с Нового времени. Оно характеризуется глубокими сдвигами в экономической, политической, духовной сферах. Несмотря на то, что позиции религии еще остаются довольно прочными, европейские страны (Германию, Англию, Францию) уже с XVI века потрясают религиозные движения Реформации. Появляется новая разновидность христианства - протестантизм, рожденный недовольством продажностью и распущенностью духовенства. Протестантизм упростил католические обряды и морально возвысил повседневную жизнь человека, истолковав его ежедневные заботы и труды как своеобразную форму служения Богу. Согласно протестантской этике, только активность человека и его успехи в делах могут свидетельствовать о его богоизбранности, ибо Бог любит тех, кто трудится. Поэтому протестанты стремились проявить себя в мирской жизни как можно активнее, и расцвет предпринимательства (как и всего капиталистического производства) не в последнюю очередь обусловлен именно протестантской моралью. Кроме того, получают также распространение различные формы свободомыслия, такие как пантеизм, деизм, скептицизм, атеизм. Мировоззренческие и этические искания, по сравнению с предшествующим средневековьем, отличаются значительной пестротой и разнонаправленностью, и, что самое главное, все они способствуют созданию своеобразного гуманистического пафоса, утверждая так или иначе центровые позиции человека в мире и пытаясь найти в человеческом разуме истоки моральности.

Философская мысль XVII-XVIII веков теоретически закрепила все новшества миропонимания и одновременно зафиксировала вполне закономерно достигнутое равновесие между «горизонталью» повседневности и «вертикалью» духовности. Томас Гоббс, Джон Локк, Бенедикт Спиноза и другие мыслители сходились на том, что мир обустроен Богом разумно и что человеческий разум несет с собой возможность дальнейшего переустройства и усовершенствования природного и социального мира. Дальнейшие философско-этические поиски еще более сосредоточивались на оправдании эмпирической действительности, и даже концепции во- 
спитания (Руссо, Дидро, Гельвеция) возводятся с помощью чисто рационалистических аргументов, отстаивающих по сути прежде всего значение повседневного существования. Земные интересы людей естественны и неодолимы, они целиком сообразны с «природой» человека, и потому нет смысла бороться с «природным» эгоизмом. Главное - научить «разумно» соотносить свои и общественные интересы. Приносимая обществу польза должна стать основным критерием новой морали: только тот, кто трудится, взамен получает моральное право пользоваться плодами труда других людей. Все разумно, естественно и правильно. Основоположник теории утилитаризма И. Бентам видел конечное назначение морали в том, чтобы способствовать естественному стремлению людей испытывать наслаждение. В содействии «наибольшему счастью» (то есть удовольствию) для «наибольшего числа людей» и состоит, по Бентаму, смысл этических норм и принципов. Общее благоденствие для него не что иное, как сумма благ всех отдельных лиц. Рационализм и утилитаризм окончательно закрепили авторитет повседневности и одновременно продолжили распространение новых жизненных ценностей «вширь».

Последним защитником «вертикали» высших духовных ценностей средствами рационалистической философии был, пожалуй, Иммануил Кант. Он утверждает, что моральные принципы существовали намного раньше эмпирического знания об окружающем мире (в свою очередь, эмпирические знания заложены в человеческом разуме априори). В моральных законах задается абсолютный предел человека, та первооснова и последняя черта, которую нельзя пересечь, не утратив человеческого достоинства. Поскольку человек - существо слабое и несовершенное, то моральный закон может иметь для него силу только в качестве повеления, или императива. Императив Канта - это своего рода формула отношения объективного морального закона к несовершенной человеческой воле. Категорический императив обязывает каждого человека относиться к человечеству в своем лице, или в лице кого угодно, только как к цели, и никогда как к средству. Чтобы не быть рабом своего природного эгоизма, человек должен обращаться к волевому самопринуждению. В этом состоит его долг, равнозначный чистоте морального мотива и твердости моральных убеждений. Посредством долга достигается и общность морального закона, и внутреннее достоинство самой личности. Индивидуальная воля может трансформироваться в общественную, а добродетель-слиться со счастьем только тогда, когда личность найдет в себе самой ту моральную опору, которую раньше искали вовне - в природе, в Боге, в общественной среде.

Размышления Канта посвящены внутренней «вертикали» личности, соотнесенной с «вертикалью» общечеловеческого долга. Последователи Канта, однако, в большей степени унаследовали и развили не столько его 
этику, сколько рационализм. С его именем связывают так называемую «интеллектуальную революцию», переключившую внимание философии с объекта на субъект, на исследование познавательной деятельности и установление законов человеческого мышления. Мыслящий субъект, который, познавая предметы, продуцирует, порождает знание о них, - оказался в центре кантианства и всей классической немецкой философии. Исследователи деятельности разума, его активности и конструктивности еще более укрепило культ разума, дополнив его учением о свободе.

Идея свободы сыграла почти роковую роль для всей духовной «вертикали», хотя поначалу никакой опасности никто не узрел. Напротив, много раздавалось восторженных голосов в пользу свободного разума $u$ mворческого $\partial y x a$, которым только и могут быть доступны полет фантазии и беспредельность мечты. Теоретики романтизма, например, хорошо усвоили мысль Канта о том, что гений не подчиняется правилам, а сам творит их. Все романтики страстно защищают творческую свободу художника и раскованность его духа. Благодаря романтизму утвердилась мысль о том, что действительный мир никогда не узнает подлинной свободы: он слишком громоздок и несовершенен, и что истинная свобода возможна только в сфере духа. Философский и литературный романтизм, в особенности немецкий, взывал художников уходить из «тесной удушливой жизни» в «царство идеала». В создаваемых поэтическим и музыкальным воображением мирах строились воздушные замки, клеймились бездушные деспоты, совершались неслыханне мятежи и низвергались царства. Гофман, Шиллер, Новалис, Гейне и другие романтики звали читателя за собой в «полный чудес Джиннистан». Отвергая повседневную жизнь, как бесцветную и прозаическую, романтики устремлялись ко всему необычному: их волновали быт и нравы далеких стран и экзотических народов, загадочные минувшие эпохи, народные предания и мифы, яркие и необыкновенные картины природы. Воспаряя над повседневностью, романтизм противостоял утилитарно-эмпирическим идеям, носители которых уверяли, что человеческий род ведет нескончаемую «разумную» войну с природой. Для романтиков природа-объект не покорения, а поклонения, и потому лишь поэзия и искусство являются самыми подходящими средствами для проникновения в ее тайны, не нарушающие ее первозданной гармонии. Природа - образец гармонии, которой так недостает социальному миру.

Романтизм ценен тем, что отстаивает высоты человеческого духа в эпоху «разумного эгоизма» и прагматизма «земных» интересов. Романтики, унаследовав традиции средневековья и Возрождения, открывших «внутреннего человека» и «человека-мастера», творца всех вещей и самого себя, продолжили погружение в необычайно сложную глубину и «внутреннюю бесконечность» человеческой личности. Человек для ро- 
мантиков - малая вселенная, целый микрокосм. Они - защитники свободы, суверенности и самоценности личности, в которой, по словам Шеллинга, заключен весь «пафос земного», вся «острота жизни». Единичное и неповторимое в человеке стало своего рода культом индивидуального, который служил романтикам своеобразной самозащитой от нараставшей нивелировки индивидов в буржуазном обществе. И этот их интерес еще не перерастает в эгоистическое самолюбование или самозабвенное копание в бессознательном.

Романтизм уникален и неповторим как исторический, мировоззренческий и философско-этический пласт мировой культуры. Он оказался своего рода высшей точкой антипросветительского движения, прокатившегося почти по всем европейским странам и осудившего Просвещение за его прагматизм и мораль «разумного эгоизма», за то, что столь страстно ожидаемое общество, порожденное «естественным светом разума», которое предвещали передовые умы Европы, воплотило в себе непредполагаемые ранее контрасты и духовное опустошение личности. Проступили такие черты жизни, которых, казалось бы, не должен был иметь «строй цивилизации», и этот новый виток противоречий бедности и богатства смутил многих и возмутил не одну мыслящую голову. Именно в противовес всей глубине и всеобщности разочарования в действительности, в возможностях цивилизации и прогресса у романтиков вырастает почти отчаянная тяга к «бесконечному», к абсолютным и универсальным идеалам, рождается страстная и всеохватывающая жажда борьбы, обновления и совершенствования. В настроения протеста против царящего в мире зла у поздних романтиков вплетаются настроения безнадежности, отчаяния и «мировой скорби», а разочарование разрастается до «космического пессимизма». Возможности социального переустройства и оздоровления морали казались утраченными навсегда: мир предстал «лежащим во зле», а в человеке воскрес «древний хаос». Тема «страшного мира» с его слепой властью материальных отношений, тоской вечного однообразия повседневной жизни и иррациональностью судеб прошла через всю историю литературы, философии, драматургии, музыки, живописи Германии, Англии, Франции, Италии, Польши, Украины, России и многих других стран. Романтизм стал последним полетом Духа. От романтизма берет начало если не «горе от ума», то «горе от свободы». Свобода индивида вкупе с его разумом становится инструментом разрушения «вертикали» духовности. Рванувшаяся к романтическим идеалам «вертикаль» духовности стремительно истончается, вдох глотка «свободы творящего разума» сменяется иррациональным выдохом.

Философский рационализм, признающий разум подлинной основой познания, прошедший длительный путь от Парменида и Аристотеля до Гегеля и верно служивший делу возведения «вертикали» духа, был от- 
теснен иррационализмом А.Шопенгауэра и С.Кьеркегора: мир неразумен и бессмыслен: человеком правит не разум, а слепая воля, инстинкты, страх и отчаяние. Артур Шопенгауэр оспорил само понятие разума, утверждая, что интеллект, сам того не сознавая, функционирует не по своему рациональному плану, а по указаниям воли, которая признается философом единой основой всех личных воль и самого объективного мира. Космически-громадная воля как первопричина мира являет собой ненасытное сильное влечение, темный глухой порыв. Мир нелеп, а вся его история - это история бессмысленной флуктуации волевых искр, когда воля вынуждена пожирать саму себя. Мир - прожорливая бесконечность, любая жизнь обречена на смерть. Воля к жизни бессмысленна, как и бессмысленна сама жизнь. Страдание, по Шопенгауэру, неотвратимо присуще жизни. Воспрепятствовать страданию может только состояние духа, лишенного всякого желания, симптомом которого выступает стремление к полному аскетизму. Шопенгауэр, по аналогии с восточной культурой, видел разрешение трагедии человеческой жизни в умерщвлении плоти и в угасании рациональных исканий человека. В неустойчивости человеческого бытия и его обреченности на смерть уверен и Кьеркегор. Чрезвычайно сложная и полная противоречий человеческая жизнь не поддается усилиям рассудка понять ее, результатом чего и является подлинный «скандал для рассудка», бессилие мысли охватить понятиями все многообразие форм существования мира. Развернувшаяся в философских кругах «критика разума» привела к отрицанию и его рационалистических результатов - логических форм, устойчивых принципов познания, системности построений, основополагающих категорий. Было признано, что «природа» мысли не передается в полной мере посредством логико-категориальной аранжировки, эмоциональное богатство восприятия и мышления только страдает от «упорядочивания в систему».

«Критика разума» проследила весь путь рационализма в обратном направлении, к истокам, к парменидовскому «бытию». В свое время парменидовская версия бытия получила предпочтение, потому что выглядела более стабильной и обнадеживающей по сравнению с гераклитовской, объясняющей бытие как вечное изменение, движение, процесс. Тогда «бытие» Парменида помогло разрешить глубокие мировоззренческие проблемы. Конец XIX столетия, ознаменовавшийся не менее серьезным мировоззренческим кризисом, так же нуждался в философском осмыслении. Поскольку попытки постижения бытия как чего-то сущностного, неизменного, субстанционального, объективно-реального оказались явно исчерпанными в русле классического рационализма, то требовались какие-то новые подходы. Извлеченная на свет из глубины веков гераклитовская концепция бытия знаменовала начало эпохи постмодерна, охватившей все виды творческой деятельности. Большинство применяемых 
творческих приемов строились на отказе и ломке прежних рамок и устоев интеллектуального и художественного творчества. Постмодерн в культуре символизировал по сути унаследованную от романтизма свободу духа, но эта свобода оказалась разрушительной, поскольку стала отвергать классические устои и утверждать сиюминутные порывы творческой личности. Гераклитовская концепция бытия как нельзя лучше подошла для объяснения сложившейся ситуации во всей духовной культуре, преисполненной пессимизмом, отчаянием и безысходностью. Новизна подхода проявилась в призыве философов заменить статичное по своей сути понятие «бытие» понятием «жизнь», как более точно отражающим изменчивость и текучесть мира. Жизнь - это поток, изменение, творчество, потому она и неуловима рассудочными методами познания. «Философия жизни» (В. Дильтей, Г. Зиммель, А. Бергсон и другие) весьма существенно повлияла на мировоззренческие поиски новейшего времени. Если познание жизни средствами разума неэффективно, значит, невозможно и ее отражение через закономерное и всеобщее, будь то Бог, Абсолют, идеал, добро, гармония. Соответственно, если познание жизни осуществляется на основе нерациональных познавательных способностей (переживания, сопереживания, веры, любви, интуиции), значит жизнь может быть постигнута толъко через индивидуальное. А всякое индивидуальное противостоит закономерному. Где-то здесь, на меже неустойчивого разнообразия единичного и стабильности вечного, находится ключ к пониманию причин разрушения, ломки вместе со всеми классическими устоями и «вертикали» духовности.

Человек как субъект познания утверждался и раньше. (После Декарта и его тезиса «cogito ergo sum» бытие утрачивает атрибут объективности, и интерпретация бытия осуществляется через посредство субъекта. Человек, его сознание, его проблемы и жизнь стали восприниматься как единое и истинное бытие, а бытие самого субъекта осмысливаться в акте самопознания.) Но, если раньше человеческий разум оценивался высоко и считался условием единства «Я» и мира, то к началу XX века разуму отказано в доверии. Человек по-прежнему остается центральной фигурой всех последующих картин мироздания, но это уже совсем другой человек. Вера во всесилие разума, присущая эпохам Возрождения и Просвещения, уже существенно пошатнулась, особенно уязвимыми оказались надежды на «разумное» и оптимальное устройство социального мира. Но самое главное, произошел разрыв человека с Абсолютом, по мнению многих философов- роковой. Этот разрыв Мартин Хайдеггер назвал «онтологическим нигилизмом». Действительно, фундаментальные философские и мировоззренческие понятия, издавна крепившие и удерживавшие «вертикаль» духовной культуры (бытие, Абсолют, Бог) утратили свое основополагающее значение в миропонимании. Отказ от при- 
Знания существования высшего, независимого от человека бытия обернулся в конце концов отказом от Бога. Процесс этот шел постепенно, но в итоге все свелось к тому, что бытие стало пониматься как реальный процесс бытия людей ${ }^{3}$. А так как социальное бытие-это прежде всего процесс удовлетворения насущных материальных потребностей, то все вернулось «на круги своя»- к вечным проблемам повседневности.

В XX веке онтологический нигилизм привел к господству материализма не только в теории, но и в жизни. Материальные ценности были признаны доминирующими, главными, «смыслонесущими» в жизни отдельных людей и целых сообществ. Людям стали казаться ненужными разные трансцендентные акты и всякого рода умения выходить за пределы чувственного опыта и делать предметом изучения бытие, которое не совпадает с конечным эмпирическим миром. Философские учения среагировали на эти настроения по-своему: метафизическая проблема бытия перестала их привлекать, отодвинувшись на периферию интереса философов, которые переключились на проблемы гносеологии, экзистенциальных глубин человека, его прав и свобод.

В самом общем виде картина вырисовывается такая. Сначала, уверовав в силу собственного разума, люди поверили в свою способность изменять мир, опираясь на законы мироздания, открытые разумом. Социальные утопии, теории «научного» социализма и коммунизма - все они исходили из соображений возможности переконструировать природу и общество с помощью разума и предметно-практической деятельности человека. Человек захотел занять место Бога на Земле. Но XX век не оправдал надежд на разум: ужасающие войны, средства массового уничтожения людей, тоталитарные политические режимы, техногенные и экологические катастрофы продемонстрировали неспособность людей обустроить свою жизнь на основах разумности и справедливости. Разум не обеспечил гармонию и порядок в мире, в нем разуверились как в опоре мироздания. В XX веке отчетливо возникло ощущение безопорности, шаткости во всех сферах жизни - в экономике, политике, морали. Это ощущение

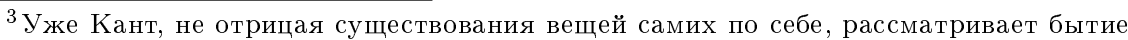
не как свойство вещей, а как связку в суждении. У Фихте впервые предметом философского анализа выступает бытие культуры, то есть бытие, созданное деятельностью человека. У Шеллинга бытие, или природа, понимается как «дремлющий разум». У Ницше бытие уже синоним жизни. Эмпириокритицизм усматривает единственную реальность бытия в человеческих ощущениях. Экзистенциализм утверждает, что человек-и только он-является истинным и конечным бытием, поскольку вопрос о бытии есть вопрос о его смысле, а смысл всегда задается самим человеком. В марксистской философии проблема бытия анализируется в двух направлениях, прежде всего как материя, с выделением разных сфер бытия: неорганической и органической природы, биосферы и социального бытия. В направлении, связанном с рассмотрением общественного бытия, исходным пунктом была практика, и бытие рассматривалось как бытие исторического, как результат социальной практической деятельности.
} 
безопорности накладывается на «онтологический нигилизм».

Отказавшись от Бога и не надеясь более на разум, человек XX века оказался один на один со своей собственной телесностъю на фоне всего невероятного разнообразия повседневности, порожденного рыночной экономикой. Стремительно стал развиваться культ тела, заменивший культ духа и разума, а это уже один из признаков язычества. Неоязычество, благодаря средствам массовой информации, быстро распространилось по планете: эротика, демонстрирование инстинктов и способов их удовлетворения, череда чувственных наслаждений, массовых оргий, наподобие дионисийских, и прочие атрибуты неудержимой экспансии человеком собственной «натуры». При условии невостребования высших ценностей или полного отказа от них, как от «лишних», требующих «ненужного напряжения», в мире возрастает ощущение бессмысленности, алогичности, неразумности жизни и отсутствия в ней каких бы то ни было гарантий. Вместо прежней иерархии ценностей сформировался тотальный плюрализм ценностей, в котором невозможно выделить приоритеmы. Возникло огромное разнообразие сиюминутных ценностей, каждая из которых замыкается на личностном «я так хочу». Мы оказались в ситуации, подобной той, что и во времена Парменида: никто не знает, как правильно жить, и никто не вправе диктовать другим, как следует жить. Все оправдано тем, что ничего в этом мире не существует вечно, и потому не может быть никаких эталонов истинности и меры бытия, высоких недосягаемых идеалов и духовных ценностей.

В современной философии человеку советуют не строить иллюзий по поводу создания новых ценностей взамен утраченных, а просто воспринимать жизнь такой, какой она есть. Мир повседневности превратился в главную иенность. В этом мире господствуют сиюминутные интересы конечных эмпирических индивидов, каждый из которых считает себя законодателем собственных этических, эстетических, политических и других устремлений. «Вертикаль» духовности осела, перекосилась, частично разрушилась. Причина этого, скорее всего, - в своеобразном разрыхлении «горизонтали» повседневности обилием товаров, удобств, услуг, соблазнов, «кнопок комфорта» и прочего. Человеку просто недосуг залетать в высоты абстракции и в «иные» умозрительные миры-он еще не все узнал и не все перепробовал в плоскости «горизонтали». Новая «экранная» культура, вытесняющая книжную, приучает к потреблению информации в готовом виде и, при всем своем позитиве, помогает лишь скользить в плоскости повседневности. Современному человеку виртуальные миры вполне заменяют умозрительные. «Древо жизни пышно зеленеет», и в этой зелени повседневности мало кто замечает, что прежнего-то «древа» ценностей уже нет, и мы рыщем по «кустам»... И только здравый смысл движет нами. 